\title{
Microarray Analysis and Identification of Novel Molecules Involved in Insulin-like Growth Factor-1 Receptor Signaling and Gene Expression
}

\author{
Joelle Dupont, ${ }^{*}$ Sandra E. Dunn, ${ }^{\dagger}$ J. Carl Barrett ${ }^{\ddagger}$ and Derek LeRoith ${ }^{\mathbb{I I}}$ \\ *Physiologie de la Reproduction et des Comportements, Unite Mixte de Recherches 6073, Institut \\ National de la Recherche Agronomique-Centre National de la Recherche Scientifique, Université \\ F. Rabelais, Tours 37380 Nouzilly, France; ' British Columbia Research Institute for Children's \\ and Women's Health, Vancouver, British Columbia, Canada; ${ }^{*}$ Center for Cancer Research, \\ National Cancer Institute, Bethesda, Maryland 20892-2440; "Clinical Endocrinology Branch, \\ National Institutes of Health, Bethesda, Maryland 20892-1758
}

\begin{abstract}
The insulin receptor (IR) and the insulin-like growth factor-1 receptor (IGF-1R) are members of the same subfamily of receptor tyrosine kinases. The two receptors phosphorylate many of the same substrates and activate the same signaling modules, including the mitogen-activated protein kinase (MAPK) and phosphatidyl inositol 3' kinase (PI3K) signaling pathways. Although the IR and IGF-1R share some redundant functions in metabolism, cell growth, differentiation, and apoptosis, they also exhibit distinct physiological roles. Some of these may be due to differences in tissue distribution, receptor structure, formation of hybrid receptors, or mechanisms of ligand binding. However, the divergent effects of insulin and IGF-1 also may be explained by specificity in the intracellular signals generated by insulin and IGF-1. In particular, the IR and IGF-1R are capable of triggering their own biological responses by using specific or preferential substrates, molecular adapters, or signaling pathways. In a recent study, we used cDNA microarray analysis to identify genes differentially regulated by insulin and IGF-1. Mouse NIH-3T3 fibroblasts expressing either the wild-type human IGF-1R or IR were stimulated with either IGF-1 or insulin, respectively. We identified 39 genes differentially regulated by insulin and IGF-1. Most of these genes had not been reported previously to be responsive to insulin or IGF-1. The genes induced by IGF-1 generally were involved in mitogenesis or differentiation, while the genes found to be induced by insulin did not conform to any particular category. In a separate study, immortalized breast epithelial cells were stimulated with IGF-1 and a cDNA microarray analysis was used to generate a profile of IGF-1regulated genes. A number of genes known to be involved in angiogenesis were found to be regulated by IGF-1. These results strongly suggest that this technology may be extremely useful in identifying groups of genes that are specifically regulated by different ligands and their activated receptors.
\end{abstract}

\section{Introduction}

Insulin and insulin-like growth factor-1 (IGF-1) are peptide hormones that are homologous in primary structure but differ in their physiological effects. 
Insulin, produced by the beta $(\beta)$ cells of the pancreas, stimulates the uptake of glucose and amino acids, inhibits gluconeogenesis, and promotes lipogenesis. IGF-1 is involved primarily in cell growth, survival, apoptosis, and differentiation. Insulin and IGF-1 mediate their biological effects by binding to their respective receptors, the insulin receptor (IR) and the IGF-1 receptor (IGF-1R). Although IR and IGF-1R are structurally and functionally similar, targeted gene knockouts in mice showed that they have both overlapping and distinct physiological roles (Nakae et al., 2001). One of the major areas of interest in this field is to understand how the specificity of IR and IGF-1R signaling is defined. In this review, we briefly compare and contrast the IR and IGF-1R signaling pathways and discuss various mechanisms that could explain the divergent physiological functions mediated by the two receptors. We then describe recent experiments using cDNA microarray analysis that have identified specific differences at the level of gene expression.

\section{Structure of the Insulin and IGF-1 Receptors}

The IR and IGF-1R are both comprised of two extracellular alpha $(\alpha)$ subunits containing ligand-binding sites and two transmembrane $\beta$ subunits transmitting the ligand-induced signal (Yarden and Ullrich, 1988). More specifically, IGF-1R and IR $\beta$ subunits consist of three domains: 1) a juxtamembrane domain, with motifs required for recruiting the major signaling adapter proteins; 2) a tyrosine kinase domain, essential for catalytic activity of the receptor; and 3) the carboxyl-terminal domain, which has several important residues for IGF-1R and IR signaling (Figure 1). As a consequence of this high level of homology, hybrid receptors, comprised of an insulin $\alpha \beta$-hemireceptor and an IGF-1 $\alpha \beta$ hemireceptor, can form in tissues and cultured cells expressing both the IR and the IGF-1R (Federici et al., 1997). Such hybrid receptors may play a role in the divergent actions of insulin and IGF-1.

\section{A. EXTRACELLULAR (LIGAND-BINDING) DOMAIN}

Despite the structural similarities between IGF-1 and insulin, the IR and IGF-1R have 100- to 1000-fold higher binding affinity for their cognate ligands. The $\alpha$ subunits have been shown to confer ligand-binding specificity (Schumacher et al., 1991). Some studies using chimeric receptors have shown that the high affinity of the IR for insulin is determined by regions adjacent to the cysteine-rich domain (Gustafson and Rutter, 1990; Schumacher et al., 1991). On the other hand, the high-affinity IGF-1 binding by the IGF-1R is determined by its cysteine-rich domain within the $\alpha$ subunit. 


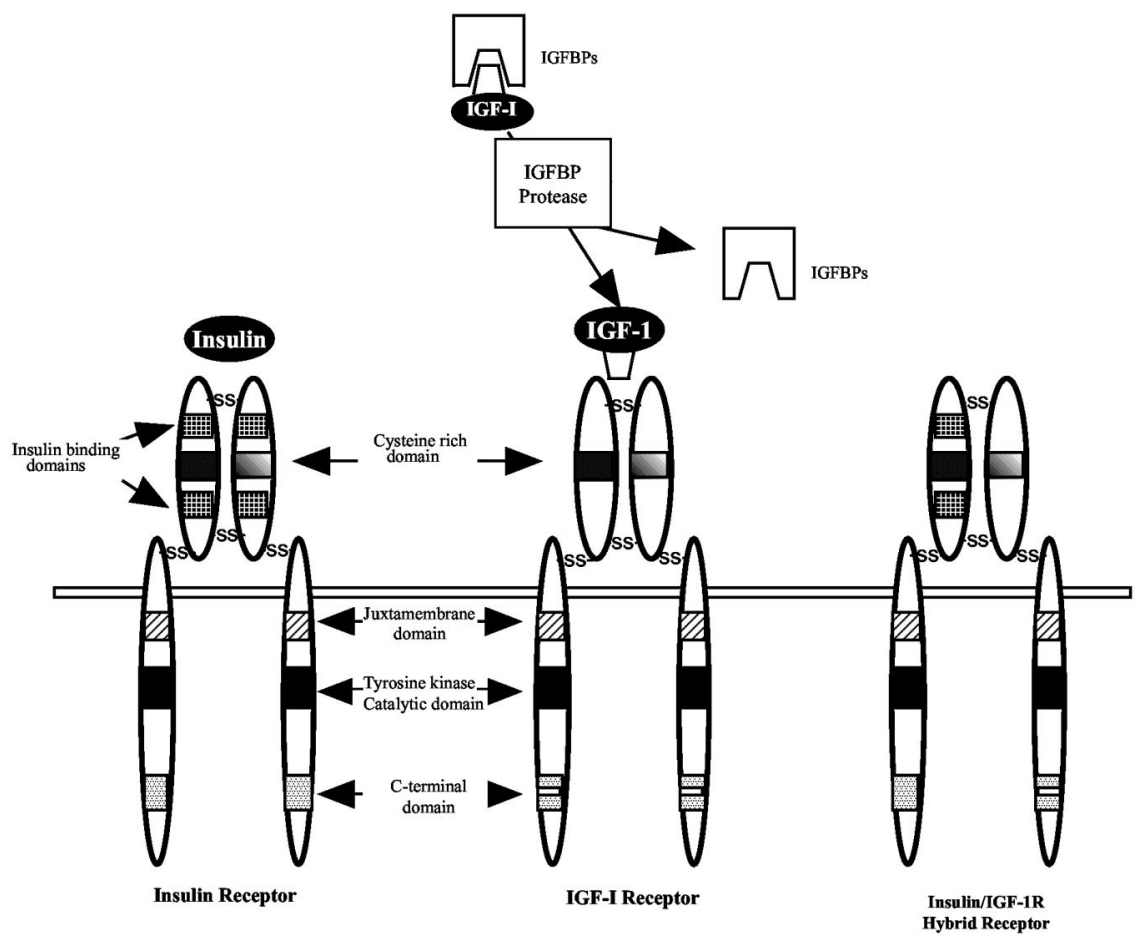

FIG. 1. The insulin-like growth factor (IGF) family of ligands, binding proteins (IGFBPs), and receptors (IGF-1R). The IGFs are bound by binding proteins in the circulation and in the extracellular matrix of the target cells. One mechanism for their release is specific protease effects on the IGFBPs, which release the IGFs to interact with their specific cell-surface receptors. IGFs may interact with IGF-1, insulin, and hybrid receptors to affect cell signaling within the target cell.

\section{B. CYTOPLASMIC DOMAIN}

Structural differences in the cytoplasmic domain of the $\beta$ subunits of the IR and IGF-1R may contribute to the divergence of these two signaling pathways. The highest degree of homology between the two receptors is found within the tyrosine kinase domain (about $84 \%$ ), whereas the region of greatest divergence between the IR and IGF-1R is found within the juxtamembrane domain (about $61 \%$ ) and the carboxyl-terminal domain (about 56\%) (Ullrich et al., 1986; Ullrich and Schlessinger, 1990). Chimeric receptors consisting of the ligandbinding domain of IR and the cytoplasmic domain of IGF-1R functioned more like the IGF-1R than the IR (Lammers et al., 1989). Similarly, chimeric IGF-1R containing the carboxyl-terminal $\beta$ subunit domain of the IR more closely resembled the IR than the IGF-1R (Tartare et al., 1994). To eliminate interactions of ligands with endogenous receptors, other chimeras were generated in which 
the extracellular portion of the neurotrophin receptor was fused to the intracellular portions of IR or IGF-1R (Siddle et al., 2001). These chimeric molecules were stably expressed in 3T3-L1 fibroblasts (Kalloo-Hosein et al., 1997) or 3T3-L1 adipocytes (Urso et al., 1999,2001) at levels comparable to those of endogenous IR or IGF-1R and activated by nerve growth factor (NGF). The TrkC-IR chimeric receptor was more effective in stimulating physiologically relevant metabolic responses, whereas the TrkC-IGF-1R was more effective in promoting mitogenesis (Urso et al., 1999). Thus, the intracellular domains of the IR and IGF-1R are likely to mediate at least part of the observed receptor specificity.

\section{Signal Transduction via IR and IGF-1R}

\section{A. COMMON SIGNALING PATHWAYS}

Many of the intracellular signaling events mediated by activation of the IR and IGF-1R are remarkably similar (White, 1994; Cheatham and Kahn, 1995; LeRoith et al., 1995) (Figure 2). Some of the shared substrates that become phosphorylated by the IGF-1R and IR include members of the insulin receptor substrate (IRS) family of proteins (IRS-1, -2, -3, and -4) (Sun et al., 1991; Lavan and Lienhard, 1993; Patti et al., 1995; Fantin et al., 1998), Gab-1 (Winnay et al., 2000), and Shc (Pelicci et al., 1992). Upon stimulation by insulin or IGF-1, tyrosine-phosphorylated IRS and Shc proteins form signaling complexes between phosphotyrosine-containing binding motifs (YXXM) and Src homology 2 (SH2) domains found in molecules such as growth factor receptor binding-2 protein (Grb2) (Lowenstein et al., 1992; Skolnik et al., 1993) and the p85 regulatory subunit of the phosphatidyl inositol 3' kinase (PI3K) (Backer et al., 1992). The phosphotyrosine residues on IRS- 1 also form docking sites for other signaling molecules, including Syp (SHPTP2) (Xiao et al., 1994), Fyn (Sun et al., 1996), Nck (Lee et al., 1993), and Crk (Beitner-Johnson et al., 1996).

By binding to Grb2, IRS proteins couple the IR and IGF-1R to the Ras/mitogen-activated protein kinase (MAPK) pathway. This pathway regulates cell growth, differentiation, and proliferation in response to insulin and IGF-1 (Blenis, 1993; Crews and Erikson, 1993). Various protein tyrosine phosphatases can regulate the activities of the IR and IGF-1R signaling systems.

\section{B. SPECIFICITY}

\section{Proximal Substrates}

To understand the mechanisms involved in the distinct physiological functions of insulin and IGF-1, some investigators searched for specific substrates for 


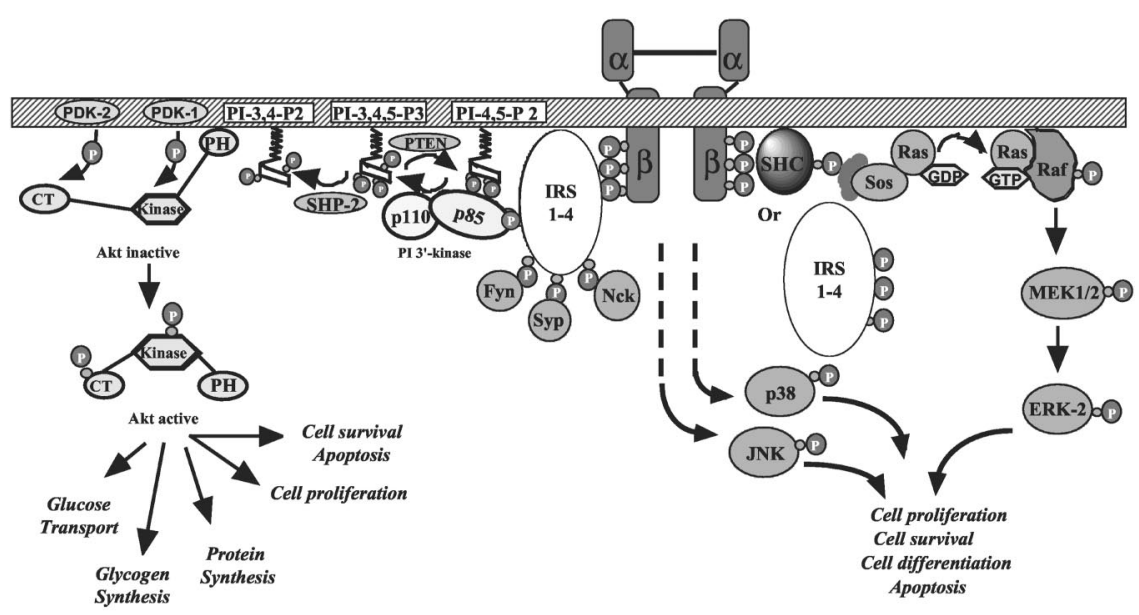

FIG. 2. Multiple signaling pathways for the IGF-1 receptors. These include the Ras/Raf/ mitogen-activated protein (MAP) kinase pathways that lead to cell proliferation. For example, the phosphatidyl inositol 3' kinase (PI3K) pathway also has multiple effects and other pathways such as the p38 MAP kinase and Jun kinase (JNK) pathways also affect these biological outcomes. Abbreviations: CT, carboxy-terminal; ERK, extracellular signal-regulated kinase; GDP, guanosine diphosphate; GTP, guanosine triphosphate; IRS, insulin receptor substrate; MEK, mitogen extracellular kinase; PDK, phosphoinositide-dependent kinase; PH, pleckstrin homology domain; PI, phosphatidylinositol; PTEN, phosphatase and tensin homologue deleted on chromosome 10; SHC, Src homology collagen; SHP, Src homology phosphatase.

IR or IGF-1R. Najjar and coworkers identified pp120, a plasma membrane glycoprotein, which is a substrate for the IR but not for the IGF-1R (Najjar et al., 1997; Soni et al., 2000). Phosphorylation of pp120 is required for its function in insulin endocytosis (Formisano et al., 1995), bile acid transport (Sippel et al., 1994), tumor suppression (Kleinerman et al., 1995), and its inhibitory effect on the mitogenic actions of insulin (Soni et al., 2000). Interestingly, when the carboxyl-terminus of the IGF-1R is replaced by an equivalent region of the IR, the chimeric IGF-1R then can bind to and phosphorylate pp120, decreasing its effect on cell growth (Soni et al., 2000). Mutation of the tyr ${ }^{1316}$ in the IR, which is not conserved in the IGF-1R, abrogates the insulin-induced tyrosine phosphorylation of pp120 and its ability to suppress the mitogenic action of insulin (Soni et al., 2000).

Some of the other substrates of the IR and IGF-1R are differentially phosphorylated in response to IGF-1 or insulin, indicating that they may mediate specific effects for both ligands. The molecular adapter Grb14 binds specifically to the regulatory kinase loop of the IR and inhibits catalytic activity (KasusJacobi et al., 1998). It recently was shown that Grb14 is three to 10 times less effective at inhibiting the catalytic activity of the IGF-1R than the IR (Bereziat 
et al., 2002). Rother and coworkers showed that the specificity of signaling may be explained by the preferential use of different substrates by the IR and IGF-1R (Rother et al., 1998). In particular, the IR was coupled preferentially to IRS-2, whereas the IGF-1R was coupled preferentially to IRS-1. This conclusion was confirmed by ablation of the IRS-1 and IRS-2 genes in mice (Araki et al., 1994; Tamemoto et al., 1994; Withers et al., 1998).

In Chinese hamster ovary (CHO) cells stably expressing either the human IR or IGF-1R, it was shown that there are differences in the complement of SH2-containing proteins recruited to IRS-1 by the two receptors (Amoui et al., 2001). In particular, the IGF-1R appears to couple IRS-1 preferentially to Grb2, whereas the IR appears to couple IRS-1 preferentially to the p85 subunit of PI3K (Amoui et al., 2001). In other recent studies, Olefsky and coworkers showed that both the IGF-1R and IR can function as G protein-coupled receptors and engage different G-protein partners. The IGF-1R utilizes G $\alpha$ i, whereas the IR does not (Dalle et al., 2001). In contrast, the IR signals through $\mathrm{G} \alpha \mathrm{q} / 11$, whereas the IGF-1R does not (Imamura et al., 1999; Dalle et al., 2001). Using the two-hybrid system, Grb10 was found to associate preferentially with the IR in mouse fibroblasts expressing either the IR or IGF-1R (Laviola et al., 1997). Using the same technique, the protein $14-3-3 \beta$ was found to bind to the IGF-1R but not to the IR (Furlanetto et al., 1997).

Recently, Ligensa and coworkers identified a new PDZ (postsynaptic density protein-95, disc large, zonula occlusions-1) domain-containing protein (IGF-1 receptor interacting protein-1, IIP-1) that interacts with the C-terminal tail of the IGF-1R but not the IR (Ligensa et al., 2001). Furthermore, the most distal three amino acids in the C-terminal tail of the IGF-1R appear to be crucial for the interaction of IIP-1 with IGF-1R. Indeed, a mutated IR tail carrying the terminal three amino acids of the IGF-1R is able to bind to IIP-1, whereas mutating any of the terminal three amino acids in the IGF-1R tail to the corresponding three amino acids in the IR abolishes the interaction with IIP-1 (Ligensa et al., 2001). Overexpression of IIP-1 in MCF-7 cells does not affect either IGF-1-dependent proliferation or IGF-1-mediated protection from apoptosis but significantly reduces cell motility (Ligensa et al., 2001). Hermanto and coworkers also identified a novel IGF-1R-interacting molecule called RACK1 (Hermanto et al., 2002). RACK1 associates specifically with the IGF-1R but not with the IR, both in yeast and in HEK293T and NIH-3T3 cells overexpressing either the IGF-1R or the IR (Hermanto et al., 2002). RACK-1 is involved in IGF-1R-mediated regulation of cell growth and transformation (Hermanto et al., 2002). However, the interaction of RACK1 with the IGF-1R but not the IR seems to be specific to certain cell types. Indeed, Kiely and coworkers showed that endogenous RACK-1 could interact with both the endogenous IGF-1R and IR in Chinese ovary siemens (COS) cells (Kiely et al., 2002). Nevertheless, these different 
receptor-specific adaptor proteins, particularly IIP-1 and RACK1, might contribute to the biological specificity of the two hormones.

\section{Signaling Pathways}

Some evidence suggests that the IR and IGF-1R may phosphorylate the same substrates but use different signaling pathways to mediate the same or different biological effects. For example, insulin induces the expression of vascular endothelial growth factor (VEGF) via the PI3K/Akt pathways in NIH-3T3 cells overexpressing the human IR, whereas IGF-1 induces VEGF expression via the mitogen extracellular kinase (MEK)/MAPK pathway in NIH-3T3 cells overexpressing human IGF-1R (Miele et al., 2000). In rat hepatic stellate cells, insulin and IGF-1 both stimulate cellular proliferation. However, both PI3K and extracellular signal-regulated kinase (ERK) are involved in IGF-1-induced mitogenesis, whereas insulin stimulated mitogenesis through a PI3K-dependent and ERK-independent pathway (Svegliati-Baroni et al., 1999). Interestingly, glycogen synthesis was more effectively stimulated by the IR than by the IGF-1R, although both receptors mediated similar activation of the Akt/protein kinase B (PKB) protein kinase in hepatocytes and in 3T3-L1 fibroblasts (Park et al., 1999). The insulin-specific stimulation of glycogen synthesis appears to involve a rapamycin-sensitive pathway in hepatocytes (Park et al., 1999).

To explain the specificities in the function of the IR and IGF-1R, some investigators suggested that downstream kinases may mediate the specific effects of the IR vs. the IGF-1R. For example, Nakae et al. reported that the transcription factor forkhead homologue to rhabdomyosarcoma (FKHR) is differentially regulated by insulin and IGF-1 in hepatocytes. The phosphorylation of one threonine residue in particular (Thr-24) appears to be induced by insulin but not by IGF-1. As this residue can be phosphorylated by PKB in vitro and PKB is also activated by IGF-1 in these cells, the authors proposed that a PKB-like kinase specifically activated by insulin may mediate this effect (Nakae et al., 2000). More recently, it has been shown that although both insulin and IGF-1 induce proliferation of murine skin keratinocytes, the action of insulin - but not IGF-1 - is mediated specifically via a protein kinase $\mathrm{C}$ delta $(\mathrm{PKC} \delta$ ) and involves activation of the sodium/potassium $\left(\mathrm{Na}^{+} / \mathrm{K}^{+}\right)$pump (Shen et al., 2001). Thus, $\mathrm{PKC} \delta$ is a multifunctional serine kinase that represents a divergence point in IR and IGF-1R signaling. In this same cell type, insulin and IGF-1 stimulate the translocation of different glucose transporters, although they both increase glucose uptake (Shen et al., 2001). Thus, insulin and IGF-1 can mediate the same or different biological responses by utilizing different signaling pathways or different intracellular mediators. 


\section{Induction of Specific Genes by the IR and IGF-1R}

Some reports have shown that insulin and IGF-1 can act on the same genes but with different outcomes. For example, in murine skin keratinocytes, insulin stimulates the expression of differentiation markers, whereas IGF-1 inhibits them (Wertheimer et al., 2000). Also, in the developing eye lens of the chicken, the level of delta-crystallin induced by IGF-1 is greater and occurs more quickly than that induced by insulin (Alemany et al., 1989). It has been shown that low concentrations of IGF-1 $(10 \mathrm{nM})$ increase the expression of uncoupling protein 3 (UCP-3) by 2-fold, whereas much higher concentrations of insulin ( $860 \mathrm{nM})$ are necessary to obtain the same effect in human neuroblastoma SH-SYSY cells (Gustafsson et al., 2001).

cDNA microarray analysis recently has been established as a powerful tool to study the effects of hormones on cellular metabolism and gene regulation on a genomic scale. Until now, this technology was used to define the effects of IGF-1 on gene expression in different cell lines (Liu et al., 2001; Oh et al., 2002) but not to compare the different gene-expression profiles induced by insulin and IGF-1. We used cDNA microarray expression profiling to identify genes that are regulated differently by IGF-1 and insulin in mouse fibroblast NIH-3T3 cells (Dupont et al., 2001b) as a first step towards understanding the molecular basis for the different functions of the IGF-1R and the IR.

\section{A. DIFFERENTIAL REGULATION OF GENE-EXPRESSION PATTERNS BY INSULIN AND IGF-1 IN NIH-3T3 FIBROBLASTS}

The biological and physiological comparison of the IR and IGF-1R is complicated by the fact that each ligand can cross-react with the other receptor and hybrid receptors can form when both receptors are expressed in the same cells. To circumvent these problems, we have compared the effect of insulin and IGF-1 in NIH-3T3 fibroblasts overexpressing either human IR (IR cells) (LevyToledano et al., 1993) or human IGF-1R (NWTb3 cells) (Blakesley et al., 1995,1996). NWTb3 and IR cells were incubated in the presence or absence of IGF-1 $(50 \mathrm{nM})$ or insulin $(50 \mathrm{nM})$ for 90 minutes, respectively. Of the 2221 genes on the mouse cDNA microarrays, we found that the expression levels of 30 were significantly induced by IGF-1 but not by insulin. In contrast, only nine genes and one expressed sequence tag (EST) were upregulated specifically by insulin but not by IGF-1 (Tables I and II). We confirmed the IGF-1- and insulin-induced regulation for 10 of these genes by Northern analysis (Figure 3). The genes that were identified as regulated by IGF- 1 and insulin are involved in various cellular functions, including proliferation, differentiation, apoptosis, cellular processes, and metabolism (Tables I and II). Interestingly, most of these genes were not known previously to be regulated by either IGF-1 or insulin. Indeed, only three genes - the Jun oncogene (Chiou and Chang, 1992; Monnier et al., 1994), $\alpha 5$ 
integrin (Palmade et al., 1994), and the early growth response-1 transcription factor (EGR-1) (Jhun et al., 1995) — had been reported to be induced by IGF-1. Furthermore, more than half of the genes upregulated by IGF-1 are associated with mitogenesis and differentiation, whereas none of the genes specifically upregulated by insulin are associated with these processes. IGF-1, but not insulin, induced the expression of two cytokine receptors (interleukin (IL) receptors 3 and 4) that have been reported to be involved in the regulation of cell growth (Keegan et al., 1994). IGF-1 also induced the expression of glial cell line-derived neurotrophic factor (GNDF), which is known to be crucial for the development and the maintenance of various neurons (Airaksinen and Saarma, 2002). IGF-1 increased the expression of the Wee-1-like kinase, which is involved in cell-cycle progression (Helmbrecht et al., 2000), and the EGR-1 transcription factor, which is known to enhance cell proliferation. These results suggest that IGF-1-induced cellular proliferation is a tightly regulated process.

Our study also suggested that insulin and IGF-1 are involved in the apoptosis process. IGF-1 treatment increased expression of the T-cell death-associated gene (TDAG)-51 and Daxx (Fas-binding) genes, whereas insulin increased expression of apoptotic protease-activating factor-1 (APAF-1) and seven in absentia homologue-1B (SIAH-1B) (Tables I and II). Importantly, IGF-1 is capable of increasing the expression of antiapoptotic genes such as Twist (Maestro et al., 1999). Thus, the induction of IGF-1- or insulin-specific genes could explain the specificity of the biological effects of these two hormones.

\section{B. TWIST EXPRESSION IS SPECIFICALLY INDUCED BY IGF-1}

In a separate study, we studied Twist, one of the genes that was specifically induced by the IGF-1-responsive gene (Dupont et al., 2001a). Twist belongs to the basic helix-loop-helix family of transcription factors, which play a central role in cell-type determination and differentiation in both vertebrates and invertebrates (Olson and Klein, 1994). IGF-1 treatment increased the abundance of Twist mRNA in NWTb3 cells, whereas insulin failed to increase Twist mRNA in IR cells. The IGF-1-induced increase in Twist expression requires activation of IGF-1R, since Twist mRNA expression was not induced in response to IGF-1 in parental NIH-3T3 cells, which express few IGF-1Rs, nor in the NKR (NIH-3T3 cells expressing an IGF-1 receptor with lysine-to-arginine substitution) cell line, which overexpresses the dominant-negative human IGF-1R (Kato et al., 1993). We also showed that injection of IGF-1 via the inferior vena cava increased Twist mRNA expression in muscle. We used various pharmacological inhibitors and a MEK-1 dominant-negative construct to investigate which IGF-1R signaling pathway was involved in the induction of Twist gene expression. These experiments demonstrated that the MEK/MAPK pathway plays a critical role in IGF-1-induced Twist expression. Using an antisense strategy, we 
TABLE I

Genes That Are Specifically Upregulated by Insulin-like Growth Factor-1 in NIH-3T3 Fibroblasts

\begin{tabular}{|c|c|c|c|c|}
\hline & Symbol & $\begin{array}{l}\text { Clone } \\
\text { number }\end{array}$ & IGF-1 & Insulin \\
\hline \multicolumn{5}{|l|}{ Mitogenesis and differentiation } \\
\hline Interleukin 3 receptor, $\alpha$-chain & IL-3R $\alpha$ & 445664 & 5.32 & 1.23 \\
\hline Colony stimulating factor, macrophage & $\mathrm{mCSF}$ & 634838 & 4.12 & 1.32 \\
\hline Glial cell line-derived neurotrophic factor & GNDF & 425671 & 3.96 & 0.80 \\
\hline Integrin $\alpha-5$ (fibronectin receptor) & $\mathrm{I} \alpha 5$ & 476908 & 3.55 & 0.94 \\
\hline Early growth response-1 & EGR-1 & 608153 & 3.65 & 0.58 \\
\hline Jun oncogene & JUN & 949554 & 3.01 & 1.11 \\
\hline Twist gene homolog & TWIST & 479367 & 2.95 & 1.54 \\
\hline Forkhead homolog 14 & FKH-14 & 541099 & 2.91 & 1.08 \\
\hline Wee 1-like protein kinase & Wee-1 & 539548 & 2.75 & 1.95 \\
\hline Insulin-like growth factor binding protein 10 & IGF-BP10 & 557055 & 2.41 & 1.48 \\
\hline $\begin{array}{l}\text { Sex-determining region Y (SRY)-box } \\
\text { containing gene } 2\end{array}$ & SRY -2 & 351033 & 2.39 & 0.59 \\
\hline Interleukin 4 receptor alpha & IL-4R $\alpha$ & 721594 & 2.30 & 0.80 \\
\hline Mouse mRNA for dbpa murine homolog & DBPA & 602275 & 2.29 & 1.65 \\
\hline $\begin{array}{l}\text { Expressed sequence tags, moderately similar } \\
\quad \text { to MAK16 (S. cerevisae })\end{array}$ & MAK16 & 537328 & 2.27 & 1.70 \\
\hline Ngfi-A binding protein 2 & NGFI-A BP-2 & 476298 & 2.31 & 1.25 \\
\hline $\begin{array}{l}\text { MAD (mothers against decapentaplegic) } \\
\text { homolog } 5 \text { (Drosophila) }\end{array}$ & MAD5 & 551401 & 2.24 & 1.49 \\
\hline Early development regulator & EDR & 616348 & 2.22 & 1.67 \\
\hline Ets variant gene 6 (TEL oncogene) & TEL & 402134 & 2.21 & 0.97 \\
\hline \multicolumn{5}{|l|}{ Apoptosis } \\
\hline $\begin{array}{l}\text { Mus musculus TDAG51 (T-cell death- } \\
\text { associated gene) }\end{array}$ & TDAG51 & 694076 & 9.00 & 1.52 \\
\hline Mus musculus Fas-binding protein (Daxx) & $\operatorname{Daxx}$ & 736796 & 5.99 & 1.55 \\
\hline \multicolumn{5}{|l|}{ Cellular processes } \\
\hline $\begin{array}{l}\text { Murine mRNA for replacement variant } \\
\text { histone H3.3 }\end{array}$ & vH3.3 & 618380 & 3.30 & 1.39 \\
\hline Kinesin heavy chain member $1 \mathrm{~A}$ & Kin1A & 492514 & 2.83 & 0.67 \\
\hline $\begin{array}{l}\text { Mouse chromatin nonhistone high-mobility } \\
\text { group protein (HMG-I(Y)) }\end{array}$ & HMG-1(Y) & 616054 & 2.64 & 1.15 \\
\hline
\end{tabular}




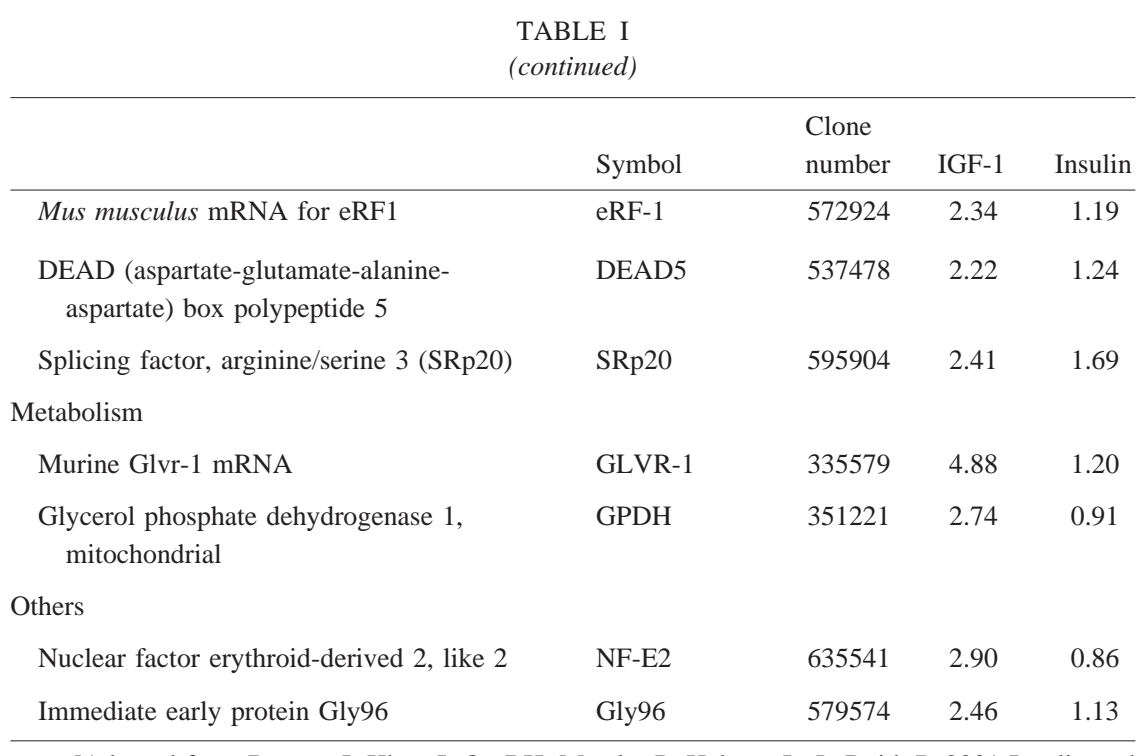

[Adapted from Dupont J, Khan J, Qu BH, Metzler P, Helman L, LeRoith D 2001 Insulin and IGF-1 induce different patterns of gene expression in mouse fibroblast NIH-3T3 cells: identification by cDNA microarray analysis. Endocrinology 142:4969-4975.]

also showed that Twist is positively involved in the antiapoptotic effects of the IGF-1R. These studies show that a gene that is regulated by IGF-1 receptor activation may, in turn, regulate the function of the IGF-1 receptor function.

\section{IGF-1-INDUCED GENES AND CANCER PROGRESSION}

IGF-1-regulated genes were studied in a preneoplastic, immortalized breast cell line, 184htert. The advantage of utilizing this cell line is that genes may be identified that are affected by IGF-1 and the IGF-1 receptor signaling pathways at an early stage in the progression of cancer. These cells were created by using retroviral technology to introduce the human telomerase reverse transcriptase gene into normal breast epithelial cells. Of the $\approx 2000$ known genes on the microarray chip, 156 (8\%) were regulated by IGF-1. These genes exhibited various patterns of regulation; whereas some were either up- or downregulated at early time points, others were regulated in a biphasic manner. The IGF-1responsive genes could be subdivided into various categories (e.g., transcription factors, cell cycle-related genes, genes involved in cancer progression, signaling-related genes, extracellular matrix genes, genes related to metabolism). Interestingly, IGF-1 regulated a large number of genes involved in angiogenesis. Many genes known to stimulate angiogenesis were upregulated 
TABLE II

Genes That Are Specifically Upregulated by Insulin in NIH-3T3 Fibroblasts

\begin{tabular}{lllll}
\hline & & Clone & \\
& Symbol & ID & IGF-1 & Insulin \\
\hline $\begin{array}{l}\text { Morphogenesis and development } \\
\text { Mouse alpha-B crystallin mRNA }\end{array}$ & CRY $\alpha$ B & 605970 & 1.56 & 2.28 \\
$\quad$ Calponin H1, smooth muscle & CNNh1 & 557012 & 1.27 & 2.10 \\
$\begin{array}{l}\text { Apoptosis } \\
\text { Apoptotic protease activating factor 1 }\end{array}$ & APAF-1 & 657503 & 1.33 & 2.20 \\
$\begin{array}{l}\text { Seven in absentia 1B } \\
\text { Cellular processes }\end{array}$ & SIAH-1B & 618379 & 1.30 & 2.04 \\
$\quad$ Microtubule-associated protein tau & TAU & 552102 & 1.36 & 2.23 \\
$\begin{array}{l}\text { Integrin alpha 6 } \\
\text { Cytochrome P450 2d10 }\end{array}$ & I $\alpha 6$ & 584662 & 1.63 & 2.05 \\
$\begin{array}{l}\text { Others } \\
\text { Prolactin receptor }\end{array}$ & & & 1.46 & 2.34 \\
$\begin{array}{l}\text { Delta-aminolevulinate dehydratase } \\
\text { Expressed sequence tags, highly similar to } \\
\text { envelope (ENV) polyprotein precursor }\end{array}$ & & & & \\
\hline
\end{tabular}

[Adapted from Dupont J, Khan J, Qu BH, Metzler P, Helman L, LeRoith D 2001 Insulin and IGF-1 induce different patterns of gene expression in mouse fibroblast NIH-3T3 cells: identification by cDNA microarray analysis. Endocrinology 142:4969-4975.]

by IGF-1, whereas inhibitors of angiogenesis such as plasminogen activator inhibitor-1 (PAI-1) and metalloproteases were inhibited by IGF-1 (Table III). The effects of IGF-1 on many of these genes - including c-fos, VEGF, Fas ligand, cyp1A1, cyp1B1, interleukin-1 $\beta$, and uPA - were validated by other techniques. Many of the genes that are regulated by IGF-1 are also responsive to the hypoxia-inducible factor-1alpha (HIF- $1 \alpha$ ) and cAMP response binding protein (CREB) transcription factors. Indeed, IGF-1 induced nuclear translocation of HIF- $1 \alpha$ and the phosphorylated form of CREB, thereby inducing gene expression.

Thus, this study demonstrated that IGF-1 regulates the expression of many genes involved in cancer progression. This new information may be helpful when considering gene targeting for therapeutic uses in the treatment of cancer. 


\section{Fold stimulation}

\begin{tabular}{|c|c|c|c|c|c|}
\hline & B3 & C43 & IR & IGF-1 & INSULIN \\
\hline GDNF & $=$ & $=-\infty$ & $=$ & $4.2 \pm 0.2$ & 1.0 \\
\hline EGR-1 & $=$ & - - & & $8.4 \pm 0.7$ & 1.0 \\
\hline mCSF & 0 & $\omega$ & $\cos 0$ & $6.2 \pm 0.2$ & 2.1 \\
\hline TDAG51 & $=$ & $=0$ & $6=$ & $4.3 \pm 0.3$ & 1.7 \\
\hline GLVR-1 & $m \infty$ & $-\infty$ & -6 & $3.8 \pm 0.1$ & 1.2 \\
\hline TWIST & $-i=$ & $-=$ & $--i$ & $2.7 \pm 0.3$ & 1.2 \\
\hline eRF1 & - & $=$ & $3=$ & $2.5 \pm 0.4$ & 1.3 \\
\hline Wee-1 & $\div 6$ & $20+6$. & 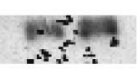 & $3.5 \pm 0.6$ & 1.6 \\
\hline PRLR & $=-$ & $=-$ & $=$ & $1.0 \pm 0.2$ & 2.7 \\
\hline$I \alpha 6$ & $5=$ & 류 & $=$ & $1.4 \pm 0.3$ & 2.7 \\
\hline $\begin{array}{l}\text { IGF-1 } \\
\text { Insulin }\end{array}$ & $\begin{array}{l}-+ \\
--\end{array}$ & $\begin{array}{l}-+ \\
--\end{array}$ & $\begin{array}{l}-- \\
-+\end{array}$ & & \\
\hline
\end{tabular}

FIG. 3. Confirmation of the specific gene expression by IGF-1 or insulin using Northern blot analysis. Northern blot analysis was performed using RNA from cells expressing IGF-1 receptors (B3 and C43) or insulin receptors (IR), following stimulation. The specificity of stimulated gene expression correlated with the microarray results seen in Tables I and II. Abbreviations: CSF, colony-stimulating factor; EGR, early growth response; GDNF, glial cell line-derived neurotrophic factor; GLVR, gibbon ape leukemia virus receptor; PRLR, prolactin receptor; TDAG, T-cell death-associated gene. [Reprinted with permission from Dupont J, Khan J, Qu BH, Metzler P, Helman L, LeRoith D 2001 Insulin and IGF-1 induce different patterns of gene expression in mouse fibroblast NIH-3T3 cells: identification by cDNA microarray analysis. Endocrinology 142:49694975. Copyright The Endocrine Society.]

\section{Conclusion and Future Directions}

The purpose of this review is to bring the possible applications of this exciting new technology to the attention of researchers. While cDNA microarray analysis is 
TABLE III

Genes Specifically Affected by IGF-1 in Breast Epithelial Cells

B-cell lymphoma-2 interacting killer

c-fos

Cytochrome P450 1A1 and 1B1

Ferrodoxine reductase

GADD45 (growth arrest and DNA damage)

Interleukin 1 beta

Jun B

Low-density lipoprotein-related protein

Plasminogen activator inhibitor-1

Transferrin

Vascular endothelial growth factor

[Adapted from Oh JS, Kucab JE, Bushel PR, Martin K, Bennett L, Collins J, DiAugustine RP, Barrett JC, Afshari CA, Dunn SE 2002 Insulin-like growth factor-1 inscribes a gene expression profile for angiogenic factors and cancer progression in breast epithelial cells. Neoplasia 4:204-217.]

associated with a number of technical hurdles and experimental flaws, its utility has enormous potential, if used carefully, with multiple controls and constant validation. This approach may prove to be useful as a rapid screening test to identify the many genes that are differentially regulated in different tissues and systems. In particular, it may lead to the identification of genes not previously known to be affected by a particular process. Furthermore, in studying the progression of disease states and variations in gene expression, in various models, it may prove to be the more rapid and economical method. Numerous other applications undoubtedly will emerge as more investigators utilize this technology.

\section{REFERENCES}

Airaksinen MS, Saarma M 2002 The gdnf family: signalling, biological functions and therapeutic value. Nat Rev Neurosci 3:383-394

Alemany J, Zelenka P, Serrano J, de Pablo F 1989 Insulin-like growth factor I and insulin regulate delta-crystallin gene expression in developing lens. J Biol Chem 264:17559-17563

Amoui M, Craddock BP, Todd Miller W 2001 Differential phosphorylation of IRS-1 by insulin and insulin-like growth factor I receptors in Chinese hamster ovary cells. J Endocrinol 171: 153-162

Araki E, Lipes MA, Patti ME, Bruning JC, Haag B III, Johnson RS, Kahn CR 1994 Alternative pathway of insulin signalling in mice with targeted disruption of the IRS-1 gene. Nature 372:186-190

Backer JM, Myers MG Jr, Shoelson SE, Chin DJ, Sun XJ, Miralpeix M, Hu P, Margolis B, Skolnik EY, Schlessinger J, et al. 1992 Phosphatidylinositol 3'-kinase is activated by association with IRS-1 during insulin stimulation. EMBO J 11:3469-3479 
Beitner-Johnson D, Blakesley VA, Shen-Orr Z, Jimenez M, Stannard B, Wang LM, Pierce J, LeRoith D 1996 The proto-oncogene product c-Crk associates with insulin receptor substrate-1 and 4PS. Modulation by insulin growth factor-I (IGF) and enhanced IGF-I signaling, J Biol Chem 271:9287-9290

Bereziat V, Kasus-Jacobi A, Perdereau D, Cariou B, Girard J, Burnol AF 2002 Inhibition of insulin receptor catalytic activity by the molecular adapter Grb14. J Biol Chem 277:48454852

Blakesley VA, Kato H, Roberts CT Jr, LeRoith D 1995 Mutation of a conserved amino acid residue (tryptophan 1173) in the tyrosine kinase domain of the IGF-I receptor abolishes autophosphorylation but does not eliminate biologic function. J Biol Chem 270:2764-2769

Blakesley VA, Scrimgeour A, Esposito D, Le Roith D 1996 Signaling via the insulin-like growth factor-I receptor: does it differ from insulin receptor signaling? Cytokine Growth Factor Rev 7:153-159

Blenis J 1993 Signal transduction via the MAP kinases: proceed at your own RSK. Proc Natl Acad Sci USA 90:5889-5892

Cheatham B, Kahn CR 1995 Insulin action and the insulin signaling network. Endocr Rev $16: 117-142$

Chiou ST, Chang WC 1992 Insulin-like growth factor I stimulates transcription of the c-jun proto-oncogene in Balb/C 3T3 cells. Biochem Biophys Res Commun 183:524-531

Crews CM, Erikson RL 1993 Extracellular signals and reversible protein phosphorylation: what to Mek of it all. Cell 74:215-217

Dalle S, Ricketts W, Imamura T, Vollenweider P, Olefsky JM 2001 Insulin and insulin-like growth factor I receptors utilize different $\mathrm{G}$ protein signaling components. J Biol Chem 276:15688-15695

Dupont J, Fernandez AM, Glackin CA, Helman L, LeRoith D 2001a Insulin-like growth factor 1 (IGF-1)-induced twist expression is involved in the anti-apoptotic effects of the IGF-1 receptor. J Biol Chem 276:26699-26707

Dupont J, Khan J, Qu BH, Metzler P, Helman L, LeRoith D 2001b Insulin and IGF-1 induce different patterns of gene expression in mouse fibroblast NIH-3T3 cells: identification by cDNA microarray analysis. Endocrinology 142:4969-4975

Fantin VR, Sparling JD, Slot JW, Keller SR, Lienhard GE, Lavan BE 1998 Characterization of insulin receptor substrate 4 in human embryonic kidney 293 cells. J Biol Chem 273:1072610732

Federici M, Porzio O, Zucaro L, Fusco A, Borboni P, Lauro D, Sesti G 1997 Distribution of insulin/insulin-like growth factor-I hybrid receptors in human tissues. Mol Cell Endocrinol 129:121-126

Formisano P, Najjar SM, Gross CN, Philippe N, Oriente F, Kern-Buell CL, Accili D, Gorden P 1995 Receptor-mediated internalization of insulin. Potential role of pp120/HA4, a substrate of the insulin receptor kinase. J Biol Chem 270:24073-24077

Furlanetto RW, Dey BR, Lopaczynski W, Nissley SP 1997 14-3-3 proteins interact with the insulin-like growth factor receptor but not the insulin receptor. Biochem J 327:765-771

Gustafson TA, Rutter WJ 1990 The cysteine-rich domains of the insulin and insulin-like growth factor I receptors are primary determinants of hormone binding specificity. Evidence from receptor chimeras. J Biol Chem 265:18663-18667

Gustafsson H, Adamson L, Hedander J, Walum E, Forsby A 2001 Insulin-like growth factor type 1 upregulates uncoupling protein 3. Biochem Biophys Res Commun 287:1105-1111

Helmbrecht K, Zeise E, Rensing L 2000 Chaperones in cell cycle regulation and mitogenic signal transduction: a review. Cell Prolif 33:341-365 
Hermanto U, Zong CS, Li W, Wang LH 2002 RACK1, an insulin-like growth factor I (IGF-I) receptor-interacting protein, modulates IGF-I-dependent integrin signaling and promotes cell spreading and contact with extracellular matrix. Mol Cell Biol 22:2345-2365

Imamura T, Vollenweider P, Egawa K, Clodi M, Ishibashi K, Nakashima N, Ugi S, Adams JW, Brown JH, Olefsky JM $1999 \mathrm{G}$ alpha-q/11 protein plays a key role in insulin-induced glucose transport in 3T3-L1 adipocytes. Mol Cell Biol 19:6765-6774

Jhun BH, Haruta T, Meinkoth JL, Leitner W, Draznin B, Saltiel AR, Pang L, Sasaoka T, Olefsky JM 1995 Signal transduction pathways leading to insulin-induced early gene induction. Biochemistry 34:7996-8004

Kalloo-Hosein HE, Whitehead JP, Soos M, Tavare JM, Siddle K, O'Rahilly S 1997 Differential signaling to glycogen synthesis by the intracellular domain of the insulin versus the insulin-like growth factor-1 receptor. Evidence from studies of TrkC-chimeras. J Biol Chem 272:24325-24332

Kasus-Jacobi A, Perdereau D, Auzan C, Clauser E, Van Obberghen E, Mauvais-Jarvis F, Girard J, Burnol AF 1998 Identification of the rat adapter Grb14 as an inhibitor of insulin actions. J Biol Chem 273:26026-26035

Kato H, Faria TN, Stannard B, Roberts CT Jr, LeRoith D 1993 Role of tyrosine kinase activity in signal transduction by the insulin-like growth factor-I (IGF-I) receptor. Characterization of kinase-deficient IGF-I receptors and the action of an IGF-I-mimetic antibody (alpha IR-3). J Biol Chem 268:2655-6126

Keegan AD, Nelms K, Wang LM, Pierce JH, Paul WE 1994 Interleukin 4 receptor: signaling mechanisms. Immunol Today 15:423-432

Kiely PA, Sant A, O'Connor R 2002 RACK1 is an insulin-like growth factor 1- (IGF-1) receptor-interacting protein that can regulate IGF-1-mediated Akt activation and protection from cell death. J Biol Chem 277:22581-22589

Kleinerman DI, Troncoso P, Lin SH, Pisters LL, Sherwood ER, Brooks T, von Eschenbach AC, Hsieh JT 1995 Consistent expression of an epithelial cell adhesion molecule (C-CAM) during human prostate development and loss of expression in prostate cancer: implication as a tumor suppressor. Cancer Res 55:1215-1220

Lammers R, Gray A, Schlessinger J, Ullrich A 1989 Differential signalling potential of insulinand IGF-1-receptor cytoplasmic domains. EMBO J 8:1369-1375

Lavan BE, Lienhard GE 1993 The insulin-elicited 60-kDa phosphotyrosine protein in rat adipocytes is associated with phosphatidylinositol 3-kinase. J Biol Chem 268:5921-5928

Laviola L, Giorgino F, Chow JC, Baquero JA, Hansen H, Ooi J, Zhu J, Riedel H, Smith RJ 1997 The adapter protein Grb10 associates preferentially with the insulin receptor as compared with the IGF-I receptor in mouse fibroblasts. J Clin Invest 99:830-837

Lee CH, Li W, Nishimura R, Zhou M., Batzer AG, Myers MG Jr, White MF, Schlessinger J, Skolnik EY 1993 Nck associates with the SH2 domain-docking protein IRS-1 in insulinstimulated cells. Proc Natl Acad Sci USA 90:11713-11717

LeRoith D, Werner H, Beitner-Johnson D, Roberts CT Jr 1995 Molecular and cellular aspects of the insulin-like growth factor I receptor. Endocr Rev 16:143-163

Levy-Toledano R, Accili D, Taylor SI 1993 Deletion of C-terminal 113 amino acids impairs processing and internalization of human insulin receptor: comparison of receptors expressed in CHO and NIH-3T3 cells. Biochim Biophys Acta 1220:1-14

Ligensa T, Krauss S, Demuth D, Schumacher R, Camonis J, Jaques G, Weidner KM 2001 A PDZ domain protein interacts with the C-terminal tail of the insulin-like growth factor-1 receptor but not with the insulin receptor. J Biol Chem 276:33419-33427

Liu T, Lai H, Wu W, Chinn S, Wang PH 2001 Developing a strategy to define the effects of insulin-like growth factor-1 on gene expression profile in cardiomyocytes. Circ Res 88:12311238 
Lowenstein EJ, Daly RJ, Batzer AG, Li W, Margolis B, Lammers R, Ullrich A, Skolnik EY, Bar-Sagi D, Schlessinger J 1992 The SH2 and SH3 domain-containing protein GRB2 links receptor tyrosine kinases to ras signaling. Cell 70:431-442

Maestro R, Dei Tos AP, Hamamori Y, Krasnokutsky S, Sartorelli V, Kedes L, Doglioni C, Beach DH, Hannon GJ 1999 Twist is a potential oncogene that inhibits apoptosis. Genes Dev 13:2207-2217

Miele C, Rochford JJ, Filippa N, Giorgetti-Peraldi S, Van Obberghen E 2000 Insulin and insulin-like growth factor-I induce vascular endothelial growth factor mRNA expression via different signaling pathways. J Biol Chem 275:21695-21702

Monnier D, Boutillier AL, Giraud P, Chiu R, Aunis D, Feltz P, Zwiller J, Loeffler JP 1994 Insulin-like growth factor-I stimulates c-fos and c-jun transcription in PC12 cells. Mol Cell Endocrinol 104:139-145

Najjar SM, Blakesley VA, Li Calzi S, Kato H, LeRoith D, Choice CV 1997 Differential phosphorylation of pp120 by insulin and insulin-like growth factor-1 receptors: role for the C-terminal domain of the beta-subunit. Biochemistry 36:6827-6834

Nakae J, Barr V, Accili D 2000 Differential regulation of gene expression by insulin and IGF-1 receptors correlates with phosphorylation of a single amino acid residue in the forkhead transcription factor FKHR. EMBO J 19:989-996

Nakae J, Kido Y, Accili D 2001 Distinct and overlapping functions of insulin and IGF-I receptors. Endocr Rev 22:818-835

Oh JS, Kucab JE, Bushel PR, Martin K, Bennett L, Collins J, DiAugustine RP, Barrett JC, Afshari CA, Dunn SE 2002 Insulin-like growth factor-1 inscribes a gene expression profile for angiogenic factors and cancer progression in breast epithelial cells. Neoplasia 4:204-217

Olson EN, Klein WH 1994 bHLH factors in muscle development: dead lines and commitments, what to leave in and what to leave out. Genes Dev 8:1-8

Palmade F, Sechoy-Chambon O, Coquelet C, Bonne C 1994 Insulin-like growth factor-1 (IGF-1) specifically binds to bovine lens epithelial cells and increases the number of fibronectin receptor sites. Curr Eye Res 13:531-537

Park BC, Kido Y, Accili D 1999 Differential signaling of insulin and IGF-1 receptors to glycogen synthesis in murine hepatocytes. Biochemistry 38:7517-523

Patti ME, Sun XJ, Bruening JC, Araki E, Lipes MA, White MF, Kahn CR 1995 4PS/insulin receptor substrate (IRS)-2 is the alternative substrate of the insulin receptor in IRS-1-deficient mice. J Biol Chem 270:24670-24673

Pelicci G, Lanfrancone L, Grignani F, McGlade J, Cavallo F, Forni G, Nicoletti I, Pawson T, Pelicci PG 1992 A novel transforming protein (SHC) with an SH2 domain is implicated in mitogenic signal transduction. Cell 70:93-104

Rother KI, Imai Y, Caruso M, Beguinot F, Formisano P, Accili D 1998 Evidence that IRS-2 phosphorylation is required for insulin action in hepatocytes. J Biol Chem 273:17491-17497

Schumacher R, Mosthaf L, Schlessinger J, Brandenburg D, Ullrich A 1991 Insulin and insulin-like growth factor-1 binding specificity is determined by distinct regions of their cognate receptors. J Biol Chem 266:19288-19295

Shen S, Alt A, Wertheimer E, Gartsbein M, Kuroki T, Ohba M, Braiman L, Sampson SR, Tennenbaum T 2001 PKCdelta activation: a divergence point in the signaling of insulin and IGF-1-induced proliferation of skin keratinocytes. Diabetes 50:255-264

Siddle K, Urso B, Niesler CA, Cope DL, Molina L, Surinya KH, Soos MA 2001 Specificity in ligand binding and intracellular signalling by insulin and insulin-like growth factor receptors. Biochem Soc Trans 29:513-525

Sippel CJ, Fallon RJ, Perlmutter DH 1994 Bile acid efflux mediated by the rat liver canalicular bile acid transport/ecto-ATPase protein requires serine 503 phosphorylation and is regulated by tyrosine 488 phosphorylation. J Biol Chem 269:19539-19545 
Skolnik EY, Lee CH, Batzer A, Vicentini LM, Zhou M, Daly R, Myers MJ Jr, Backer JM, Ullrich A, White MF, et al. 1993 The SH2/SH3 domain-containing protein GRB2 interacts with tyrosine-phosphorylated IRS1 and Shc: implications for insulin control of ras signalling. EMBO J 12:1929-1936

Soni P, Lakkis M, Poy MN, Fernstrom MA, Najjar SM 2000 The differential effects of pp120 (Ceacam 1) on the mitogenic action of insulin and insulin-like growth factor 1 are regulated by the nonconserved tyrosine 1316 in the insulin receptor. Mol Cell Biol 20:3896-3905

Sun XJ, Rothenberg P, Kahn CR, Backer JM, Araki E, Wilden PA, Cahill DA, Goldstein BJ, White MF 1991 Structure of the insulin receptor substrate IRS-1 defines a unique signal transduction protein. Nature 352:73-77

Sun XJ, Pons S, Asano T, Myers MG Jr, Glasheen E, White MF 1996 The Fyn tyrosine kinase binds Irs- 1 and forms a distinct signaling complex during insulin stimulation. J Biol Chem 271:10583-10587

Svegliati-Baroni G, Ridolfi F, Di Sario A, Casini A, Marucci L, Gaggiotti G, Orlandoni P, Macarri G, Perego L, Benedetti A, Folli F 1999 Insulin and insulin-like growth factor-1 stimulate proliferation and type I collagen accumulation by human hepatic stellate cells: differential effects on signal transduction pathways. Hepatology 29:1743-1751

Tamemoto H, Kadowaki T, Tobe K, Yagi T, Sakura H, Hayakawa T, Terauchi Y, Ueki K, Kaburagi Y, Satoh S, et al. 1994 Insulin resistance and growth retardation in mice lacking insulin receptor substrate-1. Nature 372:182-186

Tartare S, Mothe I, Kowalski-Chauvel A, Breittmayer JP, Ballotti R, Van Obberghen E 1994 Signal transduction by a chimeric insulin-like growth factor-1 (IGF-1) receptor having the carboxyl-terminal domain of the insulin receptor. J Biol Chem 269:11449-11455

Ullrich A, Schlessinger J 1990 Signal transduction by receptors with tyrosine kinase activity. Cell 61:203-212

Ullrich A, Gray A, Tam AW, Yang-Feng T, Tsubokawa M, Collins C, Henzel W, Le Bon T, Kathuria S, Chen E, et al. 1986 Insulin-like growth factor I receptor primary structure: comparison with insulin receptor suggests structural determinants that define functional specificity. EMBO J 5:2503-2512

Urso B, Cope DL, Kalloo-Hosein HE, Hayward AC, Whitehead JP, O'Rahilly S, Siddle K 1999 Differences in signaling properties of the cytoplasmic domains of the insulin receptor and insulin-like growth factor receptor in 3T3-L1 adipocytes. J Biol Chem 274:30864-30873

Urso B, Niesler CU, O'Rahilly S, Siddle K 2001 Comparison of anti-apoptotic signalling by the insulin receptor and IGF- I receptor in preadipocytes and adipocytes. Cell Signal 13:279-285

Wertheimer E, Trebicz M, Eldar T, Gartsbein M, Nofeh-Moses S, Tennenbaum T 2000 Differential roles of insulin receptor and insulin-like growth factor-1 receptor in differentiation of murine skin keratinocytes. J Invest Dermatol 115:24-29

White MF 1994 The IRS-1 signaling system. Curr Opin Genet Dev 4:47-54

Winnay JN, Bruning JC, Burks DJ, Kahn CR 2000 Gab-1-mediated IGF-1 signaling in IRS-1deficient 3 T3 fibroblasts. J Biol Chem 275:10545-10550

Withers DJ, Gutierrez JS, Towery H, Burks DJ, Ren JM, Previs S, Zhang Y, Bernal D, Pons S, Shulman GI. et al. 1998 Disruption of IRS-2 causes type 2 diabetes in mice. Nature 391:900-904

Xiao S, Rose DW, Sasaoka T, Maegawa H, Burke TR Jr, Roller PP, Shoelson SE, Olefsky JM 1994 Syp (SH-PTP2) is a positive mediator of growth factor-stimulated mitogenic signal transduction. J Biol Chem 269:21244-21248

Yarden Y, Ulirich A 1988 Molecular analysis of signal transduction by growth factors. Biochemistry 27:3113-3119 